Technical Note / Nota Técnica

\title{
Multiple water governance models: Ecuador as a case study
}

\author{
Múltiples modelos de gobernanza del agua: Ecuador como caso de estudio
}

\author{
Juan Pinos \\ Facultad de Ciencia y Tecnología, Universidad del Azuay, Cuenca, Ecuador. \\ Autor para la correspondencia.jpinos@uazuay.edu.ec \\ Fecha de recepción: 15 de mayo de 2020 - 29 de mayo de 2020
}

\begin{abstract}
Appropriate water management is essential for healthy urban and rural metabolism. Unfortunately, many challenges are associated with water governance, encompassing varying degrees of cooperation and conflict. This technical note describes the multiple water governance models in place in Ecuador such as public, private, community, and partnerships; supported by literature, and discusses the efficiency level of each model for drinking water supply and democratic citizen participation. The analysis articulates how the heterogeneity of governance models across the country respond to different socio-economic and environmental characteristics, and how the distinctive models of water governance lead to vast differences in how people understand and experience governance. The presentation and qualitative case comparison of the existing water management models revealed the transversal character of the problems affecting efficient water management, as well as the sector associated challenges and limitations. The note attempts to establish some insights about the conditions under which the various water management models are suitable and effective. The manuscript concludes by outlining several directions for future research.
\end{abstract}

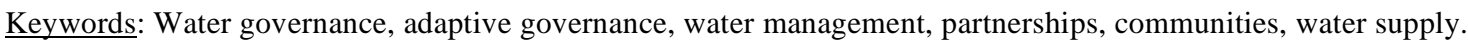

\section{RESUMEN}

La gestión adecuada del agua es esencial para un metabolismo urbano y rural saludable. Desafortunadamente, muchos desafíos están asociados con la gobernanza del agua, abarcando diversos grados de cooperación y conflicto. Esta nota técnica describe diferentes modelos de gobernanza del agua que tienen lugar en Ecuador tales como público, privado, comunitario y asociaciones; apoyado por la literatura, y discute el nivel de eficiencia de cada modelo para el suministro de agua potable y la participación democrática de los ciudadanos. El análisis articula cómo la heterogeneidad de los modelos de gobernanza en todo el país responde a diferentes características socioeconómicas y ambientales, y cómo los distintivos modelos de gobernanza del agua conducen a grandes diferencias en cómo las personas entienden y experimentan la gobernanza. Además, la presentación y la comparación cualitativa de casos de los modelos de gestión del agua existentes; reveló el carácter transversal de los problemas que afectan la gestión eficiente del agua, así como los desafíos y limitaciones asociados al sector. Esta nota intenta establecer algunas ideas sobre las condiciones bajo las cuales los diversos modelos de gestión del agua son adecuados y efectivos. El manuscrito concluye delineando varias direcciones de futuras investigaciones.

Palabras clave: Gobernanza del agua, gobernanza adaptativa, gestión del agua, asociaciones, comunidades, suministro de agua.

\section{INTRODUCTION}

Urban and rural metabolisms are systems that are sustained by the constant circulation of materials and energy, where life would be impossible without the uninterrupted flow of water (Kennedy, Cuddihy, \& EngelYan, 2007). Consequently, the sustainable development of cities is strongly linked to the governance of water. Water governance is the social function that regulates the development and management of water resources and the provision of water services (i.e., ensure adequate, equitable, and safe water) at different levels of the society in support of the economic development and social wellbeing, while not jeopardizing life and nature (Pahl-
Wostl, 2015; White et al., 2019). In the last decades, the continuous adaptability of the water governance framework greatly raised political and scientific interest. This is because a water governance system is the interconnected ensemble of political, social, economic, and administrative elements that performs the function of water governance (Pahl-Wostl, 2015). Even more, the interaction of elements, such as institutions and actors, and coevolution processes, such as the adaptation of human beings to their environment, while actively transforming and re-adapting to it, represents an enormous challenge for science, policy, and management. The subjects related to water policy have traditionally been simplistic managed with criteria predominantly from engineering, economics 
or administration, paying considerably less attention to cultural and social issues (Swyngedouw, 2004).

Ecuador is relatively a water abundant country; however, the uneven distribution of water resources and population are the major reasons for the country's water supply problems (Martínez, 2017). Urban and rural metabolisms in Ecuadorian cities are complex, varying its dynamics according to the geographical location and the local circular economy. The diverse nature of water (groundwater versus surface water), the specific resource demand (population density, urban versus rural), topography (flat versus mountainous), and extraction technologies translated into different uses of water and affected the water resources management in different ways. Social relations in conjunction with the dynamics of city-water-systems and various actors with changing power relations, influence the balance between potentially conflicting uses. For example, the transition of government authorities in the country over time resulted in the assignation of water management to a variety of institutions, together with the radical neo-liberalization process of water governance in 2007 under the government of Rafael Correa (Boelens, Hoogesteger, \& Baud, 2015). In addition, the urban situation also was and remains embedded in a framework of external forces, such as climate or technology.

From a legal framework, in the article No. 318 of the Ecuadorian constitution, several key mandates are found: "Water is the strategic national patrimony of the State....", "All forms of water privatization are prohibited", "Water management will be exclusively public or community", "The Estate, through the unique water authority, will be directly responsible for the planning and management of water resources....'. The last point refers to the National Water Secretariat (abbreviated as SENAGUA) created as the governmental entity that controls and regulates the allocation of water resources in Ecuador. However, directly or indirectly several different public or private institutions became also actors in the management of water resources, leading into an overlapping of functions and responsibilities, which in most cases resulted in the duplication of studies and infrastructure investments (Fernández \& Buitrón, 2012).

The spatial heterogeneity of Ecuador's available water resources in conjunction with different urban and rural metabolisms resulted in time in a variety of water governance models. Governance models refer to the various forms through which governance can be realized (Pahl-Wostl, 2019). Several worldwide comparative analyses of water governance models have been carried out; however, little attention was paid to examine how these systems emerged, what determines the differences between governance models, and which governance model exhibits, for example, better performance in Ecuador. The present study describes the different water governance models currently in operation in Ecuador. A case study approach was used to assess how the governance styles address the water management challenges. Finally, the article complements the literature that questions the effects of different water governance models in the hydro-social cycle and describes some gaps and formulates some questions for further research.

\section{WATER GOVERNANCE MODELS}

Three main governance models for water access and management can be defined:

1. Privative management (also named market governance): This model focuses on the provision of services related to drinking water supply, where corporations through concessions (time-limited contracts) take the administration over the assets. The participation of a private company does not extend to ownership of the assets. Commonly, the cost of capital is high, but it leads in the water sector to an increase in efficiency and innovation. There is an institutional closure to the democratic management of water, where citizen participation, rights, and principles of equity are not included.

2. Governmental management (also named hierarchical governance): The state through its public entities is in charge of protecting, preserving, and managing the sources of water to satisfy the consumption needs of the population. This model is based on two fundamental pillars: the first is the link between the political and the social, and the second is the link between the citizens themselves and the territory.

3. Community management (also named network governance): Social structures created by groups of inhabitants in peri-urban and rural areas where the service does not usually arrive from public or private entities. By means of statutes of self-government, joint work, and election of leaders in an open, simple and democratic way, they direct their efforts to establish a system of capture, purification, distribution, and payment for water. Community management focuses on the shared responsibility of all members of the community, as well as factors such as co-management, collaboration, or selfgovernment.

Further information about the differences between the three governance styles can be found in Pahl-Wostl (2015). In addition, depending on the stakeholders involved in the water governance for a specific region, different partnerships can be derived such as publicprivate partnerships and public-public partnerships (also named hybrid governance) (Phumpiu \& Gustafsson, 2009).

\section{METHODOLOGY}

The present manuscript is based on an evidence-focused review of research and review papers, including grey literature, and the official websites of different government institutions. Qualitative text analysis was performed consisting of the disintegration of existing texts and their synthesis, including the reintroduction of domain-specific elements, into new texts that bring together the essential aspects of the object to be analyzed. The analysis was qualitative in its nature because it focused on rationales, as opposed to quantitative research that focuses on statistical information. The followed approach enabled to provide a perspective on the multiple water governance models in Ecuador, and the discussion of the effectiveness of each model for drinking water supply and democratic citizen participation. 


\section{4.}

RESULTS

Ecuador has a political-administrative division of regions, provinces, cantons, and parishes. Therefore, nine different case studies representing different water governance models and dynamics are discussed in the following.

\section{Canton of Cuenca}

The city of Cuenca is the capital of the canton, located in the country's highland region. It is the third most populated canton of Ecuador and its capital is considered as one of the most expensive cities in the country. This case study corresponds to a governmental management model. The municipal government has an autonomous public entity called "Empresa Pública Municipal de Telecomunicaciones, Agua Potable, Alcantarillado y Saneamiento (ETAPA EP) (https://www.etapa.net.ec)" designated for the supply of drinking water and sanitation for the city and the water resources management of the area within its jurisdiction. The entity addresses several key points in the region's water resources management. First, the headwater catchments, which provide water to the population, are declared as a protected area. The key role of the entity is to have in its custody any activity that takes place within this area. Second, it has a series of high, medium, and low capacity drinking water treatment plants and quality control and assurance laboratories. In addition, its drinking water distribution system is effectively supplying $98 \%$ to the urban area, $90 \%$ to the parishes and rural areas next to roads, and $70 \%$ to the dispersed rural area; within the area of influence determined in the master plan. Finally, the wastewater collection and treatment service, i.e. the sewage and wastewater treatment system, cover $85 \%$ of the urban area and $60 \%$ in the rural area. The wastewater treatment plant treats $95 \%$ of urban wastewater.

\section{Metropolitan district of Quito}

Quito is the capital of Ecuador and the second most populated city of the country and is also located in the highland region. This case corresponds to a governmental management model. Quito has an autonomous public entity called "Empresa Pública Metropolitana de Agua Potable y Saneamiento (EPMAPS) (https://www.aguaquito.gob.ec)" providing drinking water and sanitation. The structure and operation are similar to that of the city of Cuenca; however, the large population and area represent an enormous challenge for the water resources management of the metropolitan district. In spite of this fact, Quito has the highest rates of drinking water and sewerage coverage, respectively 99.27\% and $93.60 \%$. However, Quito started the operations of its first wastewater treatment plant in 2017 and treats only a small percentage of the city's wastewater. Commonly, the wastewater is discharged in several streams that flow across the capital resulting in both environmental and health risks.

\section{Metropolitan district of Guayaquil}

Guayaquil is situated in the coastal region and is the most populated city of the country. This case study corresponds to a public-private management model, and in the district are the drinking water and sanitation services granted to a private consortium, named Interagua (https://www.interagua.com.ec) that belongs to the transnational company Veolia Environnement S.A., branded as Veolia. In 2012 was the public entity "Empresa Municipal de Agua Potable y Alcantarillado de Guayaquil (EMAPAG EP) (http://www.emapag-ep.gob.ec)" created as a regulating and controlling entity for the terms and conditions established in the concession contract. Currently, around $90 \%$ of the inhabitants have access to potable water and approximately $80 \%$ to sanitation. An operational wastewater treatment plant does not yet exist but is under construction. The wastewater treatment plant "Las Esclusas" will be the first for the city of Guayaquil and is expected to have coverage for one-third of the population. Commonly, the wastewater is discharged into the streams bordering the city and released into the sea.

\section{Canton of Samborondón and Daule}

Samborondón and Daule are small cantons located in the coastal region. Both these cantons possess a private management model. Aguas de Samborondón Amagua C.E.M. (https://www.amagua.com) company, belonging to the transnational Group INASSA, is a private provider of drinking water and sewerage service in La Puntilla Parish in Samborondón and in La Aurora Parish in Daule. The company supplies water up to $100 \%$ of the population within its action area and $85 \%$ sanitation. In addition, the company has 91 operational wastewater treatment stations of low capacity and the parameters of compliance with environmental regulations of most of these treatment plants are not acceptable.

\section{Province of Imbabura}

The province of Imbabura located in the highland region is formed by six cantons: Antonio Ante, Cotacachi, Ibarra, Otavalo, Pimampiro, and San Miguel de Urcuquí. According to the last national census carried out in 2010, 398244 people live in the province with $50 \%$ of the population in rural areas and the other $50 \%$ in urban areas. This case study is focused only on the rural sector which corresponds to a community management model. In 1979, by governmental decree No. 3327, were small community associations created with the responsibility of managing the infrastructure built by the Ecuadorian Institute of Sanitary Works (IEOS), a government entity created in 1966. These community associations go through life under the name of "Junta Administradora de Agua Potable y Alcantarillado (JAAP)" and are promoted by the government, i.e. are part of the legal state institutional framework, with the particularity that they have their own autonomy for water management. Decision making in each individual JAAP is carried out democratically through a General Assembly of members or users. The General Assembly meets twice a year in an ordinary manner, to know and approve the budgets and investments, respectively, and only extraordinary sessions are convened in cases that are necessary. The Assembly is the highest authority workspace regarding water management and makes the most important decisions, while the Committee is responsible for executing them. The main tasks of the JAAPs are the construction, operation, administration, and maintenance of the water system for drinking water supply and sanitation. Financing is obtained from the customer fee and the government (Sandoval-Moreno \& Günther, 2013). 


\section{Canton of Cañar}

This canton is located in the country's highland region, possesses around $77 \%$ rural and 33\% urban population, of which the majority lives in Cañar, the canton's capital. This case corresponds to a public-community management model, it is a public-public partnership. The Center of Support for the Rural Management of Drinking Water (CENAGRAP) is a co-management structure of drinking water services between the municipality of Cañar and the community organizations (JAAPs) of the canton. The center was created in 2002 and initially, there were 15 JAAPs. In 2011 the number of JAAPs increased to 82, in 2013 to 100 , and in 2017 to 114 , reaching 120 JAAPS at the beginning of 2019 (Coutteel, García, Robles, Solis, \& Solíz, 2011; Naula, Ojeda, Solis, Guillas, \& Padilla, 2013).

\section{Canton of Cotacachi}

It is a canton of the province of Imbabura in northern Ecuador within the highland region. The canton is formed by 2 urban and 8 rural parishes. The water governance model is an example of a public-private partnership between the community organization in Quiroga and the rural parishes UNORCAC (Union of Peasant and Indigenous Organizations of Cotacachi) in Imantag, and the NGO SODePAZ; where the latter executes a project together with UNORCAC, consisting in the installation of ozonation systems for water purification (Fernández, 2013).

\section{Cayapas Mataje Ecological Reserve (REMACAM)}

Located in Esmeraldas province within Eloy Alfaro and San Lorenzo parishes in the coastal region, of which a large and important extension is covered by mangroves. In this particular case, there is no water governance model of any kind. Inside this protected area 26 afro-Ecuadorian communities are established with their home in informal settlements, without a legal right to land and most do not have access to drinking water, sanitation, and security.

\section{Machángara River council and Chambo River committee}

These cases represent macro-public-private partnerships. Each member of the partnership is denominated as "node" and can have different dimensions, e.g., farmers associations, universities, municipalities, and governmental entities. The Machángara River council covers an area of $325 \mathrm{~km}^{2}$ in the province of Azuay and is formed by 10 nodes which are densely interconnected between them. The Chambo River committee is located in the province of Chimborazo and covers an area of 3580 $\mathrm{km}^{2}$ and is formed by 20 nodes where a considerable number of nodes are connected by only one or two nodes. Both macro-partnerships develop efforts to protect the natural resources within their watersheds (Cisneros, 2019).

\section{DISCUSSION}

The multiple water governance models within the country respond to different complex metabolisms and hydrosocial cycles between cities and regions. The public model is the most outstanding in terms of drinking water supply and sanitation coverage. The main factor for this efficiency is the higher monetary capital available for investment mainly in the urban water infrastructure and to a lesser extent in the rural areas (e.g., Cuenca). However, the demographic factor, i.e., the size and income levels of their populations, plays an important role in this model. The increasing population led to higher investments not only in the water sector but also in transversal sectors such as waste management, urban planning, air quality control, transportation, etc. The effect of the population size culminated also into a decline in the investment budget for water infrastructure resulting in deficient systems (e.g., Quito). On the other hand, population growth increased the demand for water supply and the pressure on the water catchments. Moreover, population growth, which is inherently part of a city's metabolism, implies a change in the urban water cycle.

To supply the legal quality and quantity of water, reforms have called for municipalities to join forces and coordinate with the private sector, as typical is the case in the three coastal cantons (Guayaquil, Samborondon, and Daule). The private water management transforms the relations between the public and private sectors, whereby the state becomes a facilitator, promoter, and regulator of the actions of the private sector in charge. Although they might seem isolated and rather exceptional, the concession of water and sanitation services happened as a result of articulated policy processes. In the case of Guayaquil, the provision of drinking water and sanitation was handled by the Social Christian Party, the party that reached the city governance in 1993. Since then, the water infrastructure works were carried out by concession companies primarily in areas with greater profitability. Before the privatization process was the water services on the verge of collapse due to bad policies and administration, which is reflected in effective improvement of the services since the concessions agreements. However, they established a dependency role and have taken advantage of the situation in economic terms (Swyngedouw, 2004). In this "indefinite" long-term contract, the transparency and accountability to consumers were reduced over time. This led to the dispossession of the inhabitants of the fundamental rights of water and the degradation of the resource. Generally, there are power disputes between the stakeholders involved, as a consequence of differences in interests and in part because of a perceived lack of transparency when a contract is signed with a private company. In the case of scarce economic resources, it is highly probable that there will be manipulation and abuse of control over subsistence resources. The control of water resources and the provision of drinking water services in the postmodern era is used as a fundamental tool to create power flows in societies. Therefore, water becomes an element of political and economic power, emerging from social control to exclude access to water to vulnerable social groups (Swyngedouw, 2009). Commonly, it is the tension about water as a human right and water as an economic good that is in debate within this type of model, i.e., the controversy of public water in private hands. Therefore, water security seems to depend greatly on the quality of the contract between the partnerships, e.g., output specifications, monitoring activities, chemical control, among others. In general terms, the private management can be described as efficient, effective, performance- and customer-oriented, and highly accountable for results produced depending on the 
contract terms which require extensive (and potentially costly) continuous monitoring and regulation.

The case of community management through the JAAPs in the rural area of Imbabura is a model that guarantees the rights of each member of the association but also reminds them of their duties towards the community. The principles that guide communities in the technical and social management of water have resisted the power of the state interventions, and the legal dispositions for the resolution of conflicts regarding the use and property of water among the inhabitants are in conflict with modern jurisdiction. The Assembly is the governing body for any action on water management and unfortunately cannot resolve legal disputes. Gradually, the traditional community organizations are losing power and legitimacy. The community model of water management must evolve beyond just asset management and could be maintained over time if there is political and legal ability to meet the needs of local communities and to control conflicts; the latter seems to be strongly dependent on community forms of organization (Hinojosa, Guerrero, \& Arias, 2017). The community management model in water management is reflected as common practice for rural water supply but is not an efficient or effective framework for public service delivery. One key point is the lack of technical support for the treatment of the complete drinking water cycle, i.e., collection, pumping, potabilization, etc. This triggers deficient water systems at the community scale and makes them commonly dependent on the technical assistant of government entities (Decentralized Autonomous Governments, GADs) or in some cases of ONGs. An example of the last is the case of Cotacahi. Related to this, Férnandez (2013) claimed that the motivation of beneficiaries (4226 inhabitants) linked to proper training will guarantee the maintenance of the water system and its durability as well as the protection of watersheds. These types of publicprivate partnerships have a positive impact by increasing the quality of life of rural communities, however, it can be a temporary phase. Results are only quantifiable when the project finishes after a few years, whereas long-term indicator monitoring is required for the assessment of sustainability over time. Unfortunately, systems generally stop working after technical failures some years after or by lack of interest of the people and are abandoned. In the community model, there are users who do not fully assess the health benefits of clean water and face serious problems of collective action in the management of water supply. It should be noted that within communities also conflicts can be found, shifting alliances, power, and social structures that respond to individual interests, and this complex behavior phenomenon can completely break the community management model (Cleaver, 1999).

In response to this constraint is the establishment of associations between public and community sectors of pivotal importance. The mixed "public-public model" could change the management of water resources profoundly and, hence, the relationship between water users, on the one hand, and between water regulators and local administrations, on the other hand. The case of CENAGRAP is an important model example that encompasses almost all JAAPS in the canton of Cañar and operates for water governance in agreement with the local municipality. The role of the government is to bring important financial and technical resources to local organizations and encourage a legalization process, while the role of the community organizations compensates the government's difficulties to reach isolated rural populations and reduce water inequalities (Dupuits \& Bernal, 2015). According to Naula et al. (2013) benefited in 2013 a total of 6654 families from the potable water system, corresponding to an estimated population of 26616 inhabitants. This governance model had a social impact in the JAAPs across the country, and similar to CENAGRAP, we found Pesillo-Imbabura, the largest public-community alliance in the northern area of Ecuador, covering the communities of the province of Pichincha (cantons Cayambe and Pedro Moncayo) and the province of Imbabura (cantons Otavalo, Antonio Ante and Ibarra). However, the case of CENAGRAP and PesilloImbabura are not representative of the overall situation in the country, where most of the community organizations remain isolated or reluctant to engage in partnership with public authorities; many barriers remain to create these alliances concretely. The first national network was created in 2012 bringing together a large number of the water community organizations of the country. The network is called Network of Social and Community Organizations of Water Management of Ecuador (ROSCGAE) (http://roscgae.blogspot.com). ROSCGAE pursuit three main objectives: 1) mediator between water community organizations, 2) mediator between communities and local governments, and 3) mediator toward national decision-making arenas. The most important and outstanding role within its strategic objectives is to be the official interlocutor between local community organizations and the national government.

In response to the development of resilience against changing regulations at watershed scale arose the model of macro-partnership. The Machángara River council was a denser and more centralized network which produced more resilience than The Chambo River committee, which was a more diverse network, because it was able to foster trust among its participants, perform essential functions more effectively, and produce legitimacy of its actions and outcomes. It is highlighted that changes in the regulations that homogenize stakeholder participation in the local water governance could deepen structural inequalities by making it harder for some actors to collaborate. The availability of resources to subsidize participation, the number and redundancy of connections to other networks, and the capacity to establish new external connections, improved the capacity of the macro-partnership to control the direction of this change (Cisneros, 2019).

Finally, in Ecuador, as many low- and middle-income countries, the land tenure situation adds a level of complexity to the efforts of progressive realization of water governance. Thousands of people established their home in informal settlements, without a legal right to land. Ecuadorian government continuously fight against such situations, either because they seek to protect vested interests or reserved areas for public investment, or because the areas are prone to natural hazards. As a result, the law prohibits the extension of services to families living in informal settlements. However, this is contradictory to the constitution which clearly states that drinking water supply should cover the entire population and provide the minimum vital amount of water, calculated in 2017 by SENAGUA as $200 \mathrm{~L}$ of raw water per inhabitant per day. Although the existence of the constitution, several situations exist in the country where reality is not at all in line with the constitution. A clear 
example is the afro-Ecuadorian communities in the Cayapas Mataje Ecological Reserve in Esmeraldas. This situation is illegal because it denies the rights of people to access drinking water and sanitation (Pinos \& Malo, 2018). In such situations, service providers (public or private) are left with the option of working with the government on legal and policy reform.

Given those situations, the need exists to analyze how public water rights are socially, politically, and economically transformed into fluxes of power, in order to develop the tools to counteract it (Swyngedouw, 2009). There exists significant urban-rural tension about water scarcity in Ecuador, however, it is not the result of the physical absence of water, but due to the non-prioritization of monetary resources together with political reforms affecting the multiple water governance models. Therefore, in the current generation resilience cities must develop the capacity to continually adjust and selforganize in the face of change in order to maintain the current development path in water governance or to actively transform into a new development trajectory (Boltz et al., 2019).

\section{CONCLUSIONS}

This paper presents a perspective of the multiple types of water governance models and partnerships for drinking water provision in Ecuador based on case studies. On the national scale, a variety of political, economic, and ecological interests make it difficult for partners to reach a common goal for providing water to all. Public management shows heterogeneity between the highlighted study cases. However, the models are in progress due to the assignment of government budgets which is pivotal for the maintenance and expansion of adequate coverage of drinking water services and environmental sanitation. In the concession-based water management is the private model far from democratic and efficient as shown in the analyzed case studies, where it can be inferred that political managers evade specialized justice and oversight. The government should concentrate on building up viable and democratic alternatives that allow civil society to be included in the first place. Community management is not an efficient autonomous model that presents several constraints such as the lack of a comprehensive institutional framework which hinders actors to participate due to the insecure legal environment and the lack of technical support. Public-community partnerships at the local level have demonstrated to be efficient and to bring the best of abilities at high levels of equity. ROSCGAE provides key support to the organization of the community and is at the same time mediator between water actors of the communities and government, with the recognition of all actors. On the other hand, macro-partnerships could manage larger areas with the integration of multiple stakeholders and higher budgets for investment, however, the different degree of participation of the stakeholders create conflicts in the collaboration between and among the network. The performance of partnerships for an effective outcome requires a combined effort from all actors over time.

\section{A VISION FOR FUTURE MANAGEMENT AND RESEARCH}

The coordination of transdisciplinary actors will provide a set of ideas and help us to manage water more holistically (mutual learning) and focus on solution-oriented knowledge creation, which is transferable to scientific and social practice, pivotal in sustainable water governance (White et al., 2019). Moreover, consolidated networks with multiple actor's means a redistribution and configuration of power, a legal democracy, and the involvement of citizens, however, long-term leadership of political parties could be a relevant issue to achieve strong sustainable governance. Furthermore, water governance ought to be an adaptive process in the development of safe, healthy, inclusive, responsive, and resilient cities by facing the uncertainties caused by climate change and demographic pressure. This will require an institutional change, which translates into a transformation of attitudes, ways of thinking and behaviors, on the extraction, distribution and use of water, in such a way that socionature is maintained.

Future research should be directed to address important gaps in Ecuador's water governance that would improve our understanding and water management such as the definition of governance-related values using quantitative techniques, the stimulation and development of sciencepolicy interactions to improve transboundary water governance, the conduct of in-depth case studies on corruption in the water sector, the evaluation of economic instruments such as tariffs and subsidies for sustainable urban water management, the development of sustainable tools for building democratic processes and face political barriers, and the buildup of collaborative methodological frameworks between rural groups and public water organizations.

\section{ACKNOWLEDGEMENTS}

I thank Prof. Dr. Jan Feyen for his critical and constructive comments to improve the quality of the manuscript.

\section{REFERENCES}

Boelens, R., Hoogesteger, J., \& Baud, M. (2015). Water reform governmentality in Ecuador: Neoliberalism, centralization, and the restraining of polycentric authority and community rule-making. Geoforum, 64, 281-291. https://doi.org/10.1016/j.geoforum.2013.07.005

Boltz, F., Poff, N. L., Folke, C., Kete, N., Brown, C. M., Freeman, S. S. G., Matthews, J. H., Martinez, A., \& Rockström, J. (2019). Water is a master variable: solving for resilience in the modern era. Water Security, 8, 100048. https://doi.org/10.1016/j.wasec.2019.100048

Cisneros, P. (2019). What makes collaborative water governance partnerships resilient to policy change? A comparative study of two cases in Ecuador. Ecology and Society, 24(1), 29. https://doi.org/10.5751/ES-10667-240129 
Cleaver, F. (1999). Paradoxes of participation: questioning participatory approaches to development. Journal of International Development, 11(4), 597612. https://doi.org/10.1002/(SICI)10991328(199906)11:4<597::AID-JID610>3.0.CO;2-Q

Coutteel, A., García, D., Robles, M., Solis, H., \& Solíz M. (2011). Yakukamay. Alianza públicocomunitaria: un modelo de gestión del agua. La experiencia desde el CENAGRAP. CENAGRAP, PROTOS-CEDIR, Municipio de Cañar.

Dupuits, É., \& Bernal, A. (2015). Scaling-up water community organizations: The role of intercommunity networks in multi-level water governance. Flux, 99(1), 19-31. https://doi.org/10.3917/flux.099.0019

Fernández, Á. (2013). Suministro de agua segura a comunidades indígenas de Cotacachi - Ecuador. Tesis de Maestría, Máster en Cooperación y Desarrollo, Universidad de Castilla La Mancha, España.

Fernández, N., \& Buitrón, R. (2012). The right to water and sanitation in Ecuador: Progress, limitations, and challenges. Environmental Justice, 5(2), 77-81. https://doi.org/10.1089/env.2011.0021

Hinojosa, L., Guerrero, W., \& Arias, P. (2017). Exploring water security and water demand determinants in rural areas. The case of canton Cotacachi in Ecuador. Water Resources and Rural Development, 10, 22-32. https://doi.org/10.1016/j.wrr.2018.09.001

Kennedy, C., Cuddihy, J. \& Engel-Yan, J. (2007). The changing metabolism of cities. Journal of Industrial Ecology, 11(2), 43-59. https://doi.org/10.1162/jie.2007.1107

Martínez, A. (2017). El derecho al agua en el Ecuador: un análisis desde la Ciencia Política y el Derecho Público. Universidad de Cuenca, Facultad de Jurisprudencia, Ciencias Políticas y Sociales.

Naula, Y., Ojeda, R., Solis, H., Guillas, S., \& Padilla, A. (2013). Inventario de la gestión rural del agua potable en las juntas administradoras de agua potable del CENAGRAP. Cuenca, Ecuador.
Pahl-Wostl, C. (2015). Water Governance in the Face of Global Change - From Understanding to Transformation. Springer International Publishing. https://doi.org/10.1007/978-3-319-21855-7

Pahl-Wostl, C. (2019). The role of governance modes and meta-governance in the transformation towards sustainable water governance. Environmental Science \& Policy, 91, 6-16. https://doi.org/10.1016/j.envsci.2018.10.008

Phumpiu, P., \& Gustafsson, J. (2009). When are partnerships a viable tool for development? Institutions and partnerships for water and sanitation service in Latin America. Water Resources Management, 23(1), 19-38. https://doi.org/10.1007/s11269-008-9262-8

Pinos, J., \& Malo, A. (2018). El derecho humano de acceso al agua: una revisión desde el Foro Mundial del Agua y la gestión de los recursos hídricos en Latinoamérica. Invurnus, 13(1), 12-20.

Sandoval-Moreno, A., \& Günther, M. (2013). La gestión comunitaria del agua en México y Ecuador: otros acercamientos a la sustentabilidad. Ra Ximhai, 9(2), 165-179.

Swyngedouw, E. (2004). Social power and the urbanization of water: flows of power. Oxford, UK: Oxford University Press.

Swyngedouw, E. (2009). The political economy and political ecology of the hydro-social cycle. Journal of Contemporary Water Research \& Education, 142(1), 56-60. https://doi.org/10.1111/j.1936704X.2009.00054.x

White, D., Lawless, K., Vivoni, E., Mascaro, G., Pahle, R., Kumar, I., Coli, P., Muñoz-Castillo, R., Moreda, F., \& Asfora, M. (2019). Co-Producing Interdisciplinary Knowledge and Action for Sustainable Water Governance: Lessons from the Development of a Water Resources Decision Support System in Pernambuco, Brazil. Global Challenges, 3(4), 1800012. https://doi.org/10.1002/gch2.201800012 